\title{
Field relations, petrography, and age of plutonic units in the Saint John area of southern New Brunswick
}

\author{
Chris E. White, Sandra M. Barr \\ Department of Geology, Acadia University, Wolfville, Nova Scotia BOP 1X0, Canada \\ Mary Lou Bevier \\ Geological Survey of Canada, 601 Booth Street, Ottawa, Ontario K1A OE8, Canada
}

and

\author{
Kevin A. Deveau \\ Department of Earth Sciences, Memorial University, St. John's, Newfoundland A1X 3B5, Canada
}

Date Received August 15, 1990

Date Accepted November 8, 1990

\begin{abstract}
Intrusive rocks in the Saint John area of southern New Brunswick are divided into separate plutonic units based on field relations and rock type. The oldest intrusive rocks are granodioritic orthogneisses in the Brookville Gneiss that have an igneous crystallization age of ca. $605 \mathrm{Ma}$, and a metamorphic age of ca. $564 \mathrm{Ma}$. The metamorphic age of the orthogneiss provides an approximate maximum age for post-metamorphic plutons that range in composition from gabbro to granite. One of these, the Rockwood Park Granodiorite, has a U-Pb age of $538 \pm 1 \mathrm{Ma}$. On the basis of field relations, the Rockwood Park Granodiorite occupies an intermediate position in the intrusive sequence of plutons in the Saint John area. We therefore speculate that these plutons are mainly Cambrian rather than Precambrian as has been generally assumed.
\end{abstract}

\begin{abstract}
On divise les roches intrusives de la région de Saint Jean (Nouveau-Brunswick méridional) en unités plutoniques distinctes basées sur les relations de terrain et sur le type de roche. Les plus vieilles roches intrusives sont des orthogneiss granodioritiques au sein du Gneiss de Brookville, dotés d'un âge de cristallisation ignée d'environ $605 \mathrm{Ma}$ et d'un âge métamorphique d'environ $564 \mathrm{Ma}$. L'âge métamorphique de l'orthogneiss foumit un âge maximal approximatif pour des plutons postmétamorphiques dont la composition s'étale des gabbros aux granites. Parmi ceux-ci, la Granodiorite de Rockwood Park a un âge U-Pb de 538 \pm 1 Ma. D'après les relations de terrain, la Granodiorite de Rockwood Park occupe une position intermédiaire au sein de la séquence intrusive de plutons dans la région de Saint Jean. On présume donc que ces plutons sont en grande partie cambriens et non pas précambriens comme le voulait l'opinion générale.
\end{abstract}

[Traduit par le joumal]

\section{INTRODUCTION}

The Brookville Gneiss and Green Head Group northeast of Saint John in southern New Brunswick have been intruded by a variety of granitoid plutons (Fig. 1). In the past these plutons, together with the Brookville Gneiss, have been termed the Golden Grove Intrusives (Hayes and Howell, 1937; Williams et al., 1985, p. 145). However, geological mapping has shown that these plutons have varied petrological and deformational characteristics, and that the Brookville Gneiss includes both paragneissic and orthogneissic components (e.g., Wardle, 1978; Deveau, 1989; Barr and White, 1989). Therefore the inclusion of all these rocks in a single intrusive suite is not appropriate.

The purpose of this paper is to clarify the distribution, field relationships, and rock types of plutons associated with the Green
Head Group and Brookville Gneiss, and to establish consistency in the names used for these intrusions. In addition, a new $\mathrm{U}-\mathrm{Pb}$ date from one of these plutons is presented and discussed in view of other new dates from the Brookville Gneiss (Bevier et al., 1990) and plutons elsewhere in southern New Brunswick (e.g., Currie, 1987; Bevier and Barr, 1990). Understanding of the character and age of plutonic units in the Saint John area is important because of the inappropriate extension of the use of the term Golden Grove Suite to include plutons west of Saint John (Currie, 1986, 1987, 1988a, b), and the common, but inaccurate, assumption that the Golden Grove Suite is typical of Late Precambrian plutons throughout the Avalon Terrane of the northern Appalachian orogen (e.g., O'Brien et al., 1983; Nance, 1986, 1987). 


\section{PREVIOUS WORK}

A review of previous work shows many inconsistencies in the terminology that has been used for plutonic and metamorphic rocks in the Saint John area, and litule agreement concerning their age(s). The Precambrian Portland Group of Bailey (1865) and Bailey et al. (1880) included the gneisses, granites, diorites, and gabbros of the Saint John area. However, Matthew (1894) suggested that these intrusions might be post-Silurian, based on similarities to granites that intruded Silurian rocks in northern New Brunswick. Cumming (1916) used the term Golden Grove Suite for the gneissic and plutonic rocks of the Portland Group, and also considered them to be post-Silurian.

Hayes and Howell (1937) introduced the term Green Head Formation for the sedimentary rocks of the Portland Group. They considered the Golden Grove Suite, which they termed the Golden Grove Intrusives, to be Precambrian, intermediate in age between their Green Head Formation and the Coldbrook Group, the volcanic and sedimentary rocks overlying the Portland Group. However, they also suggested that the plutonic rocks may be as young as Devonian. They assigned names to many of the individual plutons in their Golden Grove Intrusives, terminology subsequently adopted with various modifications by later workers (Wardle, 1978; Ruitenberg et al., 1979; Currie et al., 1981; Deveau, 1989).

Alcock (1938) upgraded the Green Head Formation to group status. He noted that some of the gneissic rocks appear to be recrystallized Green Head Group sedimentary rocks, although he considered most to be gneisses of intrusive origin or deformed granites. He suggested that plutonic rocks in the area are of at least two ages: Precambrian, represented by granitoid units intruded into the Green Head Group, and Devonian(?), represented mainly by granitoid rocks intruded into the Coldbrook Group.

Wardle (1978) excluded the gneissic rocks from the Golden Grove Suite and established the presence of both orthogneiss and paragneiss. He divided the gneisses into three separate packages termed the Brookville, Rockwood Park and Pleasant Point gneisses, the latter two being predominantly orthogneissic. Rast et al. (1976) and Wardle (1978) suggested that these orthogneisses acted as intrusive diapirs into the domed Brookville paragneiss, and that the paragneiss represents a highly metamorphosed equivalent of part of the Green Head Group. These authors also concluded that both the Green Head and Coldbrook groups were intruded by the Precambrian Golden Grove Suite. This view was subsequently adopted by other workers (e.g., O'Brien et al., 1983; Nance, 1987).

However, Ruitenberg et al. (1979) continued to group the gneissic rocks with the plutons of the Golden Grove Suite, and used the collective term Golden Grove Intrusive Complex. Based on results of $\mathrm{K}-\mathrm{Ar}$ and $\mathrm{Rb}-\mathrm{Sr}$ dating by numerous workers, Ruitenberg et al. (1979) concluded that the plutons associated with the Green Head Group range in age from Late Precambrian to Early Paleozoic whereas intrusive rocks in the Coldbrook Group are Early Ordovician.

Currie et al. (1981) used the term Brookville Gneiss to refer to all gneisses in the Saint John area and interpreted the gneisses to be Archean basement, reactivated and diapirically emplaced into the Green Head Group during the intrusion of the Golden Grove Suite. Currie et al. (1981) also described the plutons of the Golden Grove Suite, modifying the units of Hayes and Howell (1937) and introducing some new pluton names (see below). On the basis of Rb-Sr and U-Pb data, Olszewski and Gaudette (1982) concluded that the Brookville Gneiss is older than a postulated $800 \mathrm{Ma}$ metamorphic and plutonic event (represented by the Golden Grove Suite). Currie et al. (1981) and many subsequent workers (e.g., Currie, 1987; Nance, 1987) interpreted the gneiss to represent the continental basement upon which the overlying Green Head Group accumulated. However, recent U-Pb dates from the orthogneissic and paragneissic components of the Brookville Gneiss indicate a Late Precambrian protolith age (White et al., 1990a, b; Bevier et al., 1990), much younger than the Middle Riphean (Neohelikian) age proposed by Hofmann (1974) for the Green Head Group on the basis of stromatolites. Hence the Brookville Gneiss appears to be younger than the Green Head Group and cannot be considered its "basement".

Currie $(1986,1987,1988 \mathrm{a}, \mathrm{b})$ extended the use of the term Golden Grove Suite to plutons west of Saint John. Nance (1986, 1987) implied that the term Golden Grove Suite includes most plutonic rocks in the Avalon Terrane of southern New Brunswick and considered the suite to be Late Precambrian and co-genetic with the Coldbrook Group.

\section{PLUTONS OF THE SAINT JOHN AREA}

We propose that the term Golden Grove Intrusives be abandoned, on the basis that it includes rocks that are clearly not intrusive (paragneisses of the Brookville Gneiss) and that the plutonic components are unlikely to be part of a single intrusive suite, or to be of similar age. Instead, we propose the use of individual pluton names (Fig. 1), following as much as possible the long-established terminology of Hayes and Howell (1937). The names Milkish Head, Mayflower Lake, Rockwood Park, Fairville, and Duck Lake are all retained from Hayes and Howell (1937). The Indiantown Gabbro of Hayes and Howell (1937) does not appear to be a single mappable unit, and hence this term is no longer used (see below). The name Narrows Tonalite is used following Wardle (1978), and the new names French Village, Chalet Lake, and Hammond River are introduced for other plutons not named by Hayes and Howell (1937). Except for the Milkish Head Pluton, the dominant rock type in the pluton is used with the geographic name, following the recommendations of the International Subcommission on Stratigraphic Classification (1987). Because of its possible composite nature, the term Milkish Head Pluton is retained.

The plutons are described briefly below; more detailed descriptions of the petrology are presented in Deveau (1989).

\section{Orthogneissic component of the Brookville Gneiss}

Orthogneiss comprises less than $10 \%$ of the Brookville Gneiss (Wardle, 1978; Barr and White, 1989), and generally forms concordant sheets within the paragneiss, al though south of Green Head Island it forms a small mappable unit ("swirled 

orthogneiss" of Wardle, 1978). The orthogneiss ranges in modal composition from biotite tonalite to biotite granodiorite (Fig. 2a). It is typically strongly foliated, grey, and fine- to mediumgrained, consisting of xenoblastic and poikiloblastic quartz and plagioclase with minor biotite and interstitial microcline (Fig. 3a). No homblende is present. U-Pb dating of zircon indicates an igneous crystallization age of $605 \pm 3 \mathrm{Ma}$, and metamorphic titanite gave an age of $564 \pm 6 \mathrm{Ma}$, the minimum age for amphibolite facies metamorphism of the orthogneiss (Bevier $e t$ al., 1990).

Diffuse leucogranitic areas within the Brookville paragneiss, as described by Currie et al. (1981), may represent leucosomes produced during high-grade metamorphism of the Brookville Gneiss. It seems doubtful that the discordant zircon age of $465 \mathrm{Ma}$ for one of these granitic areas (Olszewski et al., 1980; Currie et al., 1981) is significant.

\section{French Village and other dioritic plutons}

French Village is a new name proposed for a dominantly quartz dioritic pluton in the northeastern part of the map area (Fig. 1), part of the undivided Golden Grove Intrusives of Hayes and Howell (1937). The pluton is well exposed along Highway 111 and a sample has been collected for U-Pb dating (Bevier, work in progress). Other smaller but similar dioritic intrusions throughout the study area (Fig. 1) may be correlative. These include rocks previously included in the Indiantown Gabbro and Rockwood Park amphibolite (Hayes and Howell, 1937; Wardle, 1978), and many of the "mafic bodies" which were described by Currie et al. (1981) as a major component of the map area.

The southeastern margin of the French Village Quartz Diorite is a faulted contact with volcanic rocks of the Coldbrook Group. However, the pluton has intrusive contacts with the Green Head Group, based on the presence of numerous marble and quartzite xenoliths of Green Head Group affinity throughout the pluton (Fig. 1) and the development of a contact metamorphic aureole in the Green Head Group in the French Village area. An intrusive relationship with the Brookville Gneiss is indicated by the presence of a small dioritic intrusion in the gneiss west of the main French Village Pluton and also by the presence of finegrained dioritic dykes, presumably related to the French Village Quartz Diorite, in the gneiss. The French Village Quartz Diorite is intruded by the Milkish Head Pluton; relationships are well exposed in roadcuts on Highway 111. The smaller dioritic intrusions in the city of Saint John generally display faulted and sheared contacts but are intruded by coarse-grained granite related to the Fairville Granite.

The French Village Quartz Diorite is dominantly dioritic to quartz dioritic in composition, but is gradational to tonalite (Fig. 2b). Colour and texture vary considerably, but most rocks are dark grey, medium-grained and hypidiomorphic granular (Fig. $3 b$ ), although porphyritic varieties (with homblende and/or plagioclase phenocrysts) are not uncommon. A weakly to moderately developed foliation, defined by elongate plagioclase and hornblende crystals, is commonly present.

\section{Milkish Head Pluton}

The Milkish Head Pluton is the largest intrusion in the map area (Fig. 1). Two smaller intrusions, Mayflower Lake and Narrows (Hayes and Howell, 1937; Wardle, 1978), are considered to be related to the Milkish Head Pluton because they have similar texture and mineralogy (Deveau, 1989).

Contacts between the Milkish Head Pluton and adjacent units are generally faulted but the original contacts are inferred to be intrusive. As noted above, an intrusive contact with the French Village Quartz Diorite is exposed along Highway 111 and the pluton, as well as the Mayflower Lake and Narrows plutons, contain xenoliths of fine-grained diorite. Wardle (1978) reported that the Narrows and Mayflower Lake plutons have contact metamorphic aureoles in the Green Head Group. Contacts with the Brookville Gneiss were not observed.

The Milkish Head Pluton consists of quartz diorite and tonalite, grading into granodiorite (Fig. 2c) towards the north and northwest. Currie et al. (1981) considered that the K-feldsparpoor southern and eastern parts of the Milkish Head Pluton form a separate pluton that they termed Renforth. However, our mapping suggests that the change in composition is gradational, and hence the Milkish Head Pluton is retained as a single large pluton. Like the southern and eastern parts of the Milkish Head Pluton, the Mayflower Lake and Narrows plutons are gradational between quartz diorite and tonalite (Fig. 2).

The dioritic and tonalitic rocks are mainly grey, mediumgrained and equigranular (Fig. 3c), whereas the granodioritic varieties tend to be pink to red in colour and coarse-grained (Fig. $3 d)$. The pluton is mainly unfoliated but locally a weak foliation is present as a result of alignment of mafic minerals and elongate dioritic xenoliths. Compared to the dioritic rocks assigned to the French Village Quartz Diorite and correlative units, dioritic rocks of the Milkish Head, Mayflower Lake, and Narrows plutons are more homogeneous and contain lower abundances of mafic minerals (generally less than $15 \%$ compared to more than $20 \%$ and up to $50 \%$ ). Also homblende is the dominant mafic mineral in the French Village and correlative plutons, whereas both biotite and homblende are ubiquitously present in Milkish Head, Mayflower Lake, and Narrows plutons.

\section{Rockwood Park Granodiorite}

The Rockwood Park Granodiorite forms two bodies separated by a sliver of Green Head Group marble in the vicinity of Rockwood Park (Fig. 1). As thus defined, this pluton includes the granodioritic part of the Rockwood Park plutons of Hayes and Howell (1937) and Wardle (1978) but excludes the coarser grained granitic rocks that we consider to be part of the Fairville Granite (see below). The northeastern body of the Rockwood Park Granodiorite was termed the Fisher Lakes Pluton by Currie et al. (1981), and reported to consist of biotite-hornblende granite with large quartz crystals. We found only foliated mediumgrained granodiorite outcrops around Fisher Lakes. However, coarse-grained granitic rocks occur northwest of the lakes and are 


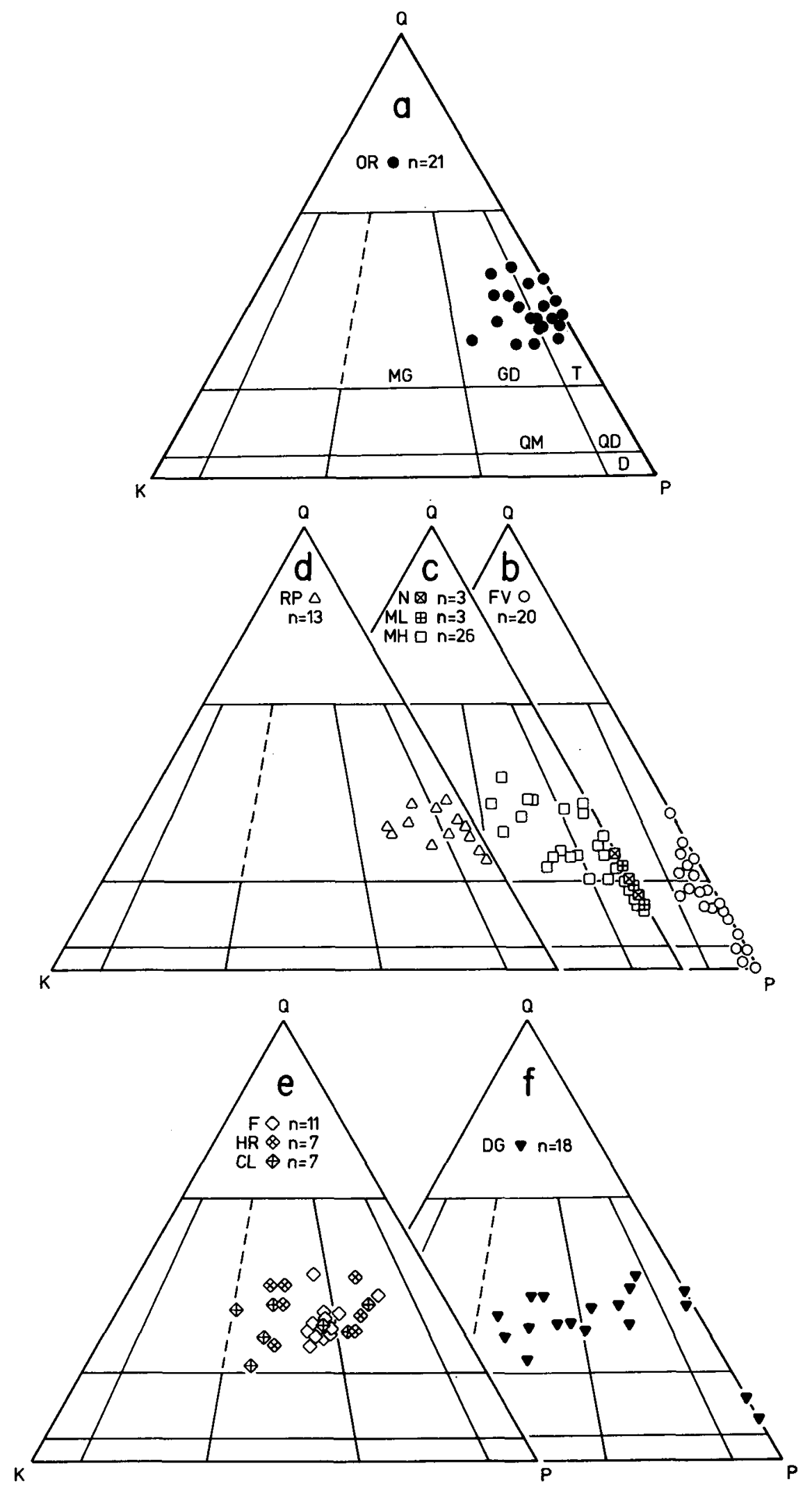

Fig. 2. Modal compositions of representative samples from plutons in the map area (excluding Duck Lake Gabbro) plotted on the Quartz (Q) - Kfeldspar (K) - Plagioclase (P) diagram with fields from Streckeisen (1976); D - diorite, QD - quartz diorite, QM - quartz monzonite, T - tonalite, GD - granodiorite, MG - monzogranite. Modal compositions obtained by counting at least 400 points in thin section or on slabs stained for K-feldspar. (a) Orthogneissic component (OR) of the Brookville Gneiss; (b) French Village Quartz Diorite and related dioritic plutons (FV); (c) Milkish Head (MH), Mayflower Lake (ML), and Narrows (N) plutons; (d) Rockwood Park Granodiorite (RP); (e) Fairville (F), Hammond River (HR) and Chalet Lake (CL) granites; (f) deformed granitoid plutons (DG). 


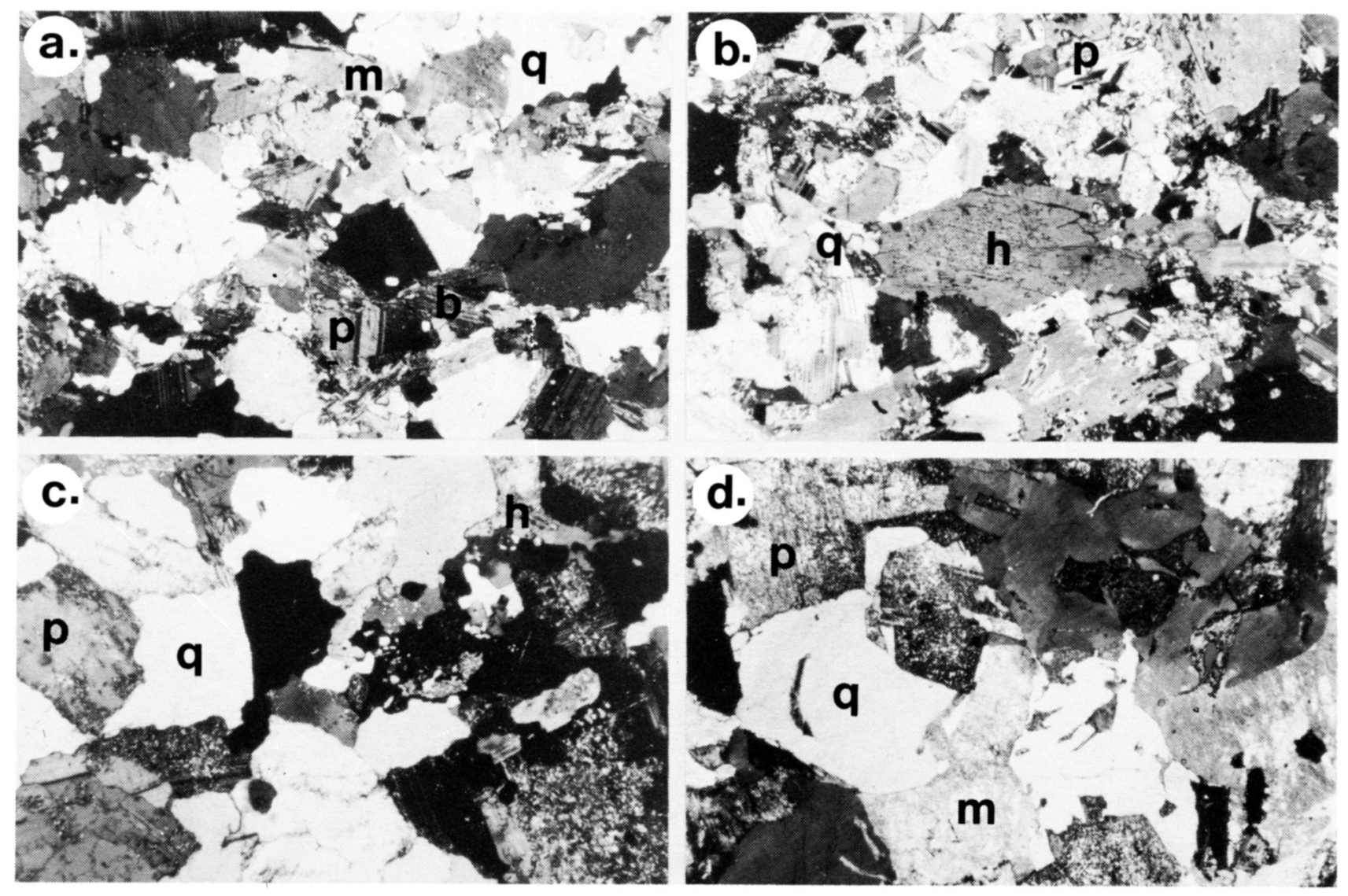

Fig. 3. Photomicrographs illustrating typical mineralogical and textural features of plutons in the Saint John area. Length of photographs is 3 mm; all are in cross-polarized light. (a) Brookville orthogneiss, consisting mainly of xenoblastic quartz(q), plagioclase(p), biotite(b), and microcline(m). Foliation is oriented parallel to the long dimension of photograph. (b) French Village Quartz Diorite, consisting mainly of plagioclase(p), and homblende(h), with minor quartz(q). (c) Tonalite of Milkish Head Pluton, showing equigranular quartz(q), plagioclase(p), and homblende(h). (d) Granodiorite of the Milkish Head Pluton, showing equigranular quartz(q), plagioclase(p), and microcline(m) with minor biotite.

included here with the Fairville Granite.

Contacts between the Rockwood Park Granodiorite and adjacent units were not observed but the presence of elongate dioritic xenoliths indicates that the pluton is younger than the French Village Quartz Diorite and other dioritic intrusions.

The Rockwood Park Granodiorite consists of grey, mediumgrained tonalite gradational to granodiorite (Figs. 2d, 4a). It is characterized by the presence of a moderate to strongly developed foliation, defined by alignment of homblende, plagioclase, and elongate dioritic xenoliths.

\section{Duck Lake Gabbro}

The Duck Lake Gabbro is located southeast of Rothesay (Fig. 1). It is mainly within the Brookville Gneiss, except on its eastern margin where it is in contact with the French Village and Milkish Head plutons. The Duck Lake Gabbro is considered to be younger than all of these units because it is unfoliated and because gabbroic dykes believed to be related to the pluton occur in the French Village Quartz Diorite.

Previous workers (e.g., Hayes and Howell, 1937; Wardle, 1978) described a second gabbroic intrusion west of the Rockwood Park Granodiorite, termed the Indiantown Gabbro. Al- though a small body of pyroxene-bearing gabbro outcrops near the Saint John River in that area (Fig. 1), most of the rocks included in the Indiantown unit appear to be dioritic rather than gabbroic. Hence we correlate these dioritic rocks with the French Village Quartz Diorite or with the deformed granitoid unit (see below), and do not use the term Indiantown. The small gabbro body is cut by granitic dykes that appear to be related to the Fairville Granite; if so, and if this gabbro body is correlative with Duck Lake, then the Fairville/Chalet Lake/Hammond River granites are younger than the gabbroic plutons.

The gabbros are medium- to coarse-grained, and composition ranges from pyroxene-rich (Fig. 4b) to feldspar-rich (anorthositic gabbro). Duck Lake appears to be a small layered intrusion, perhaps similar to the Mechanic Settlement Gabbro in the central Caledonia Highlands (Barr and White, 1988; Paktunc, 1989).

\section{Fairville, Chalet Lake, and Hammond River granites}

The Fairville Granite is well exposed in the Pleasant Point area south of Green Head Island and extends across the Saint John River north of the Rockwood Park Granodiorite (Fig. 1). As thus defined, it includes part of the Rockwood Park and Fisher Lakes 

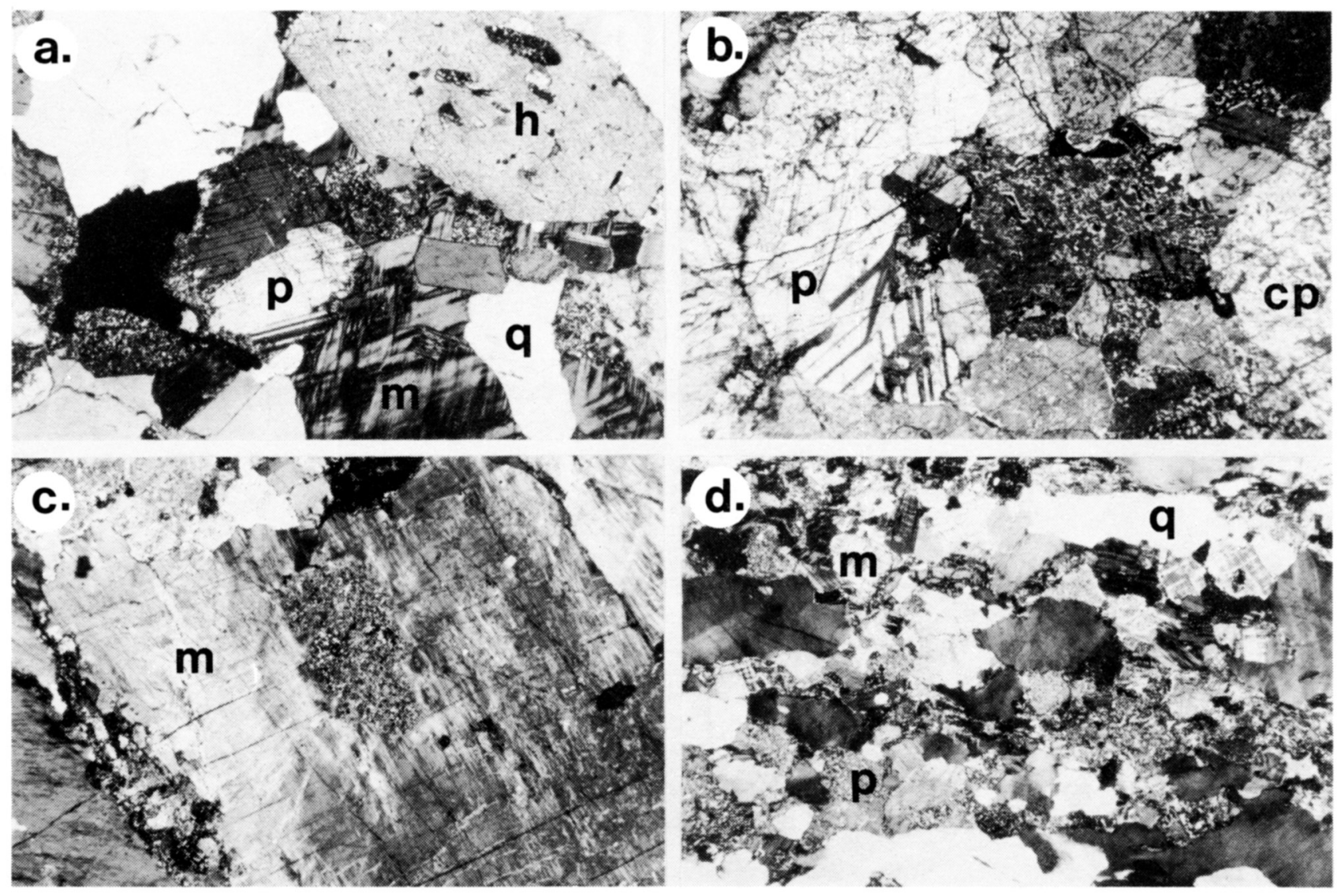

Fig. 4. Photomicrographs illustrating typical mineralogical and textural features of plutons in the Saint John area. Length of photographs is 3 mm; all are in cross-polarized light. (a) Rockwood Park Granodiorite, showing equigranular plagioclase(p), microcline(m), quartz(q), and hornblende( $h$ ). (b) Duck Lake Gabbro, showing plagioclase(p) and clinopyroxene(cp). (c) Fairville Granite, showing microcline(m) megacryst. (d) Deformed granitoid rock, consisting mainly of quartz(q), plagioclase $(p)$, and microcline $(m)$. Foliation is oriented parallel to long dimension of photograph.

plutons of Currie et al. (1981). The Chalet Lake Granite forms two small intrusions near Chalet Lake in the central part of the map area (Fig. 1). The Hammond River Granite outcrops in the extreme northeastern part of the map area along the Hammond River (Fig. 1). These plutons are similar in texture and mineralogy and are assumed to be correlative. They are interpreted to be the youngest major felsic intrusive event in the map area as they contain xenoliths of all older units.

All three plutons consist of medium- to coarse-grained monzogranite gradational to granodiorite (Figs. 2e, 4c). They are typically megacrystic, with large megacrysts of microperthitic microcline (Deveau, 1989). Locally large quartz crystals are also present, as in the area northwest of Fisher Lakes.

\section{Deformed granitoid rocks}

Pervasively deformed granitoid rocks occur in a belt extending from the southwestem part of the map area to south of the Rockwood Park Granodiorite, and also on the southern margin of the Brookville Gneiss (Fig. 1). These strongly foliated granitoid rocks vary in composition (Fig. 2f), and may represent very deformed (sheared) dioritic to granitic bodies related to the French Village, Rockwood Park, and Fairville plutons. However, because of the extent of deformation (e.g., Fig. 4d), it is not possible to assign them with certainty to any individual pluton. Previous workers have included parts of this unit with the Brookville Gneiss and Indiantown Gabbro (Wardle, 1978; Currie et al., 1981).

\section{RADIOMETRIC AGE DATA}

Ages of plutonic rocks in the Saint John area are not well constrained. Ruitenberg et al. (1979) summarized much of the $\mathrm{Rb}$-Sr and K-Ar data available at that time; these dates generally range from Ordovician to Devonian and do not appear to indicate igneous crystallization ages. The ca. $564 \mathrm{Ma}$ date for amphibolite-facies metamorphism of the Brookville orthogneiss (Bevier et al., 1990) provides a maximum age for the other plutons, as they post-dated this metamorphic event.

In an attempt to further constrain the ages of these plutons, the Rockwood Park Granodiorite was selected for U-Pb dating. The analyzed sample consists of medium- to coarse-grained hypidiomorphic inequigranular granodiorite, typical of the pluton, with a moderate to strong foliation defined by alignment of hornblende and plagioclase. Plagioclase (ca. An30) forms 44\% of the rock, anhedral quartz, $31 \%$, and interstitial perthitic micro- 
cline, $10 \%$. The mafic minerals are biotite (10\%) and homblende (5\%). Accessory phases are opaque minerals, apatite, zircon, and titanite.

Analytical procedures for separation, selection, dissolution, and analysis of zircon and titanite for U-Pb dating are described in Bevier and Barr (1990). For the zircon analyses reported here, total procedural blanks for $\mathrm{Pb}$ averaged $14 \mathrm{pg}$ and $\mathrm{U}$ blanks averaged $2 \mathrm{pg}$. For the titanite analysis, blanks were $54 \mathrm{pg}$ for $\mathrm{Pb}$ and $2 \mathrm{pg}$ for U. Errors were propagated numerically (Roddick, 1987) and are quoted at the $2 \sigma$ level, with ${ }^{207} \mathrm{~Pb} /{ }^{25} \mathrm{U}$ and ${ }^{206} \mathrm{~Pb} /{ }^{28} \mathrm{U}$ errors averaging 0.32 and $0.22 \%$, respectively, for zircon analyses, and $0.66 \%$ and $0.24 \%$, respectively, for the titanite analysis.
Ages were calculated using the decay constants of Steiger and Jăger (1977). All analyses were corrected for common $\mathrm{Pb}$ using values for $538 \mathrm{Ma}$ from Stacey and Kramers (1975).

Analytical results are given in Table 1. Zircons from the Rockwood Park Granodiorite sample are pale yellow, euhedral grains with excellent clarity and rare inclusions of colorless tubes and bubbles. The grains vary in shape from simple prisms with a dipyramid to simple prisms with a multifaceted dipyramid, and length:breadth ratio varies from 2:1 to 3:1. Titanite in this sample forms brown, subhedral to anhedral grains with excellent clarity.

Three zircon analyses and one titanite analysis cluster on or near concordia (Fig. 5). Zircon fraction B is concordant with a

Table 1. U-Pb Analytical Data.

\begin{tabular}{|c|c|c|c|c|c|c|c|}
\hline Mineral fraction & $\begin{array}{l}\text { Weight } \\
\text { (mg) }\end{array}$ & $\begin{array}{c}\mathrm{U} \\
(\mathrm{ppm})\end{array}$ & $\begin{array}{c}\mathrm{Pb}^{*} \\
(\mathrm{ppm})\end{array}$ & $\begin{array}{c}\text { Measured } \\
208 \mathrm{~Pb} /{ }^{204} \mathrm{~Pb}\end{array}$ & $\begin{array}{l}208 \mathrm{~Pb}^{*} \\
(\%)\end{array}$ & $\begin{array}{c}\text { Isotopic ratios } \\
{ }^{206} \mathrm{~Pb}^{*} / 238 \mathrm{U}\end{array}$ & $\begin{array}{l}{ }^{207} \mathrm{~Pb}^{*} / 206 \mathrm{~Pb}^{*} \\
\text { age (Ma) }\end{array}$ \\
\hline
\end{tabular}

CW-89-509A Rockwood Park granodiorite

$\begin{array}{lrrrrrrrr}\text { A. } N+149 & 0.0278 & 86.9 & 8.26 & 659 & 16.5 & 0.08721 & 0.69919 & 535.3 \pm 5.0 \\ \text { B. W }+149 & 0.0404 & 109.6 & 10.56 & 995 & 17.6 & 0.08709 & 0.69914 & 538.3 \pm 4.4 \\ \text { C. M +149 } & 0.0201 & 83.0 & 8.16 & 567 & 19.2 & 0.08720 & 0.69643 & 526.8 \pm 4.2 \\ \text { D. Titanite V +149 } & 0.1457 & 179.7 & 25.39 & 468 & 43.6 & 0.08731 & 0.69990 & 535.0 \pm 11.4\end{array}$

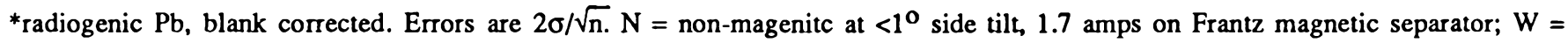
weakly magnetic at $<2^{\circ},>1^{\circ}, 1.7$ amps; $\mathrm{M}=$ magnetic at $<5^{\circ},>2^{\circ}, 1 \mathrm{amp} ; \mathrm{V}=$ very magnetic at $>5^{\circ}, 1 \mathrm{amp}$.

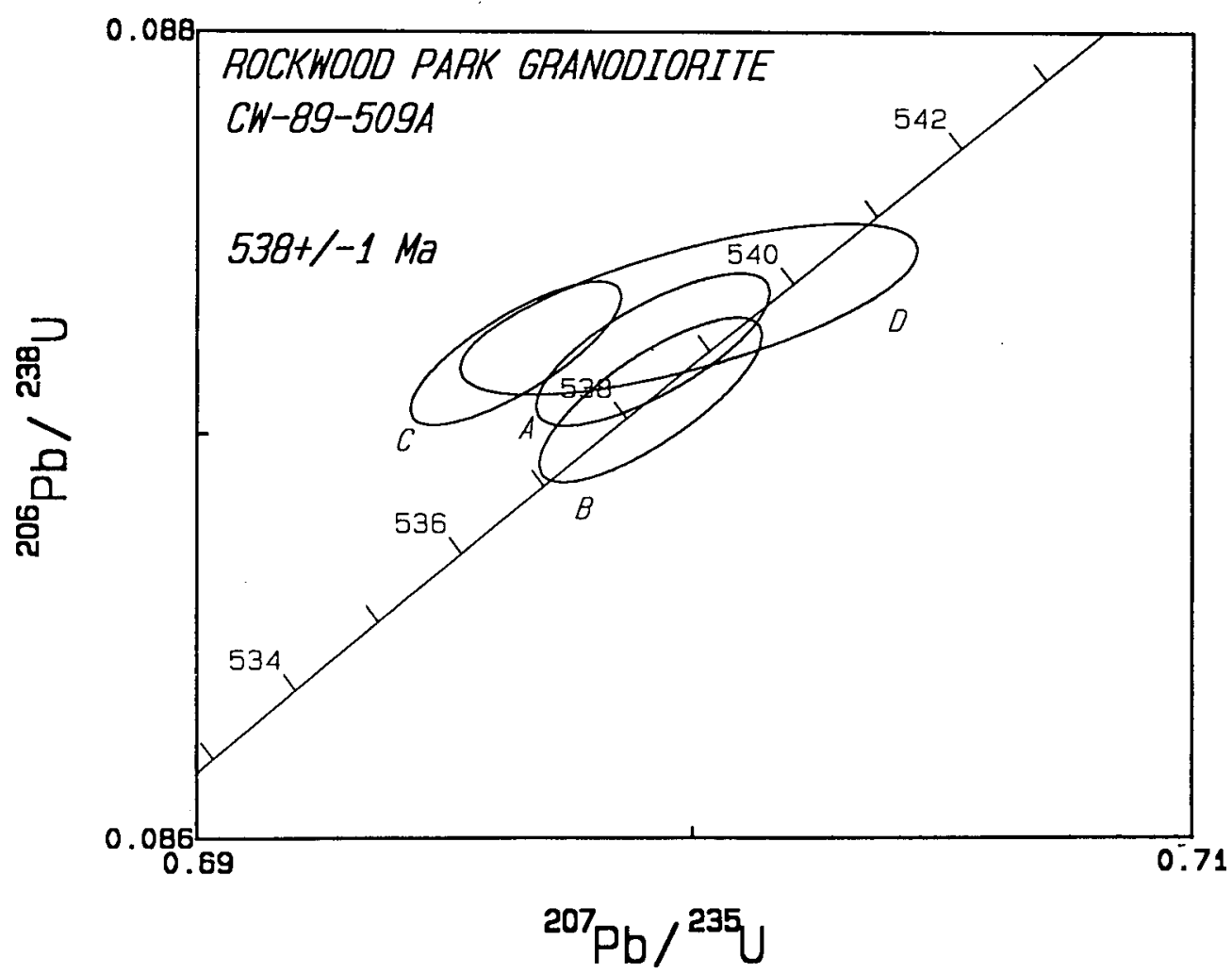

Fig. 5. U-Pb concordia plot for the Rockwood Park Granodiorite, showing $2 \sigma$ error envelopes. 
${ }^{206} \mathrm{~Pb} /{ }^{238} \mathrm{U}$ age of $538 \pm 1 \mathrm{Ma}$, and we consider this to be the best estimate of the crystallization age of the sample. The other analyses plot slightly above concordia and to the left of fraction B. The simplest explanation for this discrepancy is analytical error due to the small amounts of $\mathrm{Pb}$ analyzed from these samples. For the three analyses of zircons the amount of $\mathrm{Pb}$ analyzed varies from $0.164 \mathrm{ng}$ in fraction $\mathrm{C}$ to $0.426 \mathrm{ng}$ in fraction B. Titanite analysis (D) may plot above concordia either due to incomplete dissolution or due to incorrect estimation of the amount or composition of the common $\mathrm{Pb}$ in the sample.

\section{DISCUSSION AND CONCLUSIONS}

The date of $538 \pm 1$ Ma for the Rockwood Park Granodiorite, combined with the $564 \pm 6 \mathrm{Ma}$ date for metamorphism of the Brookville Gneiss, indicates that the plutons in the map area are Cambrian in age, if the Precambrian - Cambrian boundary is taken at ca. $570 \mathrm{Ma}$ (Palmer, 1983). Because the absolute age of the Precambrian - Cambrian boundary is uncertain and estimates range down to ca. $530 \mathrm{Ma}$ (Cowie and Johnson, 1985; Odin et al., 1985), it is possible that these plutons may be latest Precambrian.

In contrast to these Cambrian or possibly latest Precambrian dates, $\mathrm{U}-\mathrm{Pb}$ dates from plutons in the Caledonia Highlands east of the Saint John map area (Fig. 1) indicate that most are much older (615 - 625 Ma; Bevier and Barr, 1990; Watters, 1987). Therefore these two groups of plutons are not co-genetic, even though they are compositionally similar - both groups are compositionally expanded calc-alkalic I-type suites, in the sense of Pitcher (1987), typical of suites formed in continental margin subduction zones.

Some Cambrian granites occur in the Caledonia Highlands (Bonnell Brook syenogranite and related plutons; U-Pb zircon age $550 \pm 1 \mathrm{Ma}$; Bevier and Barr, 1990) but these are petrologically unlike any of the granitic plutons in the map area, as discussed by Barr and White (1988), Deveau (1989), and Barr et al. (1990). They do not consist of compositionally expanded suites but are composed dominantly of syenogranite with subordinate diorite and gabbro. They are very high level intrusions that are co-genetic with associated bimodal volcanic rocks of similar age (Bevier and Barr, 1990).

The significance of the Duck Lake Gabbro is not clear. It appears to be tholeiitic and hence not likely to be co-magmatic with the calc-alkalic dioritic to granitic plutons of the area (Deveau, 1989). It may be related to the Mechanic Settlement Gabbro in the Caledonia Highlands that has yielded a K-Ar age of $518 \pm 37 \mathrm{Ma}$ (Barr and White, 1988).

The Brookville orthogneiss has a protolith age of $605 \pm 3 \mathrm{Ma}$, indicating that it is not co-genetic with the Cambrian plutons of the Saint John area. This is consistent with its higher grade of metamorphism. The orthogneiss is similar in age to some volcanic units in the Caledonia Highlands, but the contrast in composition and metamorphic grade indicates that correlation is unlikely, as discussed by Bevier et al. (1990).

Plutonic rocks are abundant southwest of the study area, west of the Saint John River (Ruitenberg et al., 1979; Dickson, 1983; Currie, 1987). Dickson (1983) grouped many of these into the Milkish Head Complex; however, Currie (1987) divided them into separate plutons on the basis of texture and composition. On the basis of the descriptions provided by Currie (1987), the Lepreau, Talbot Road, and Red Bridge plutons are dioritic and may be related to the French Village and related units, or to the Milkish Head Pluton and correlative units. The Talbot Road Pluton has yielded $\mathrm{a}^{40} \mathrm{Ar} /{ }^{\beta 9} \mathrm{Ar}$ homblende age of ca. $520 \pm 3 \mathrm{Ma}$ (Dallmeyer and Nance, 1989), consistent with the Cambrian age of the Rockwood Park Granodiorite. Preliminary U-Pb zircon dates of ca. 555-565 Ma from two of the granitic plutons west of Saint John (Currie, 1988a, b) are not compatible with direct correlation with granitic plutons (Fairville, Chalet Lake, Hammond River) in the study area because the latter are younger than the 538 Ma Rockwood Park Granodiorite. However, detailed petrological comparisons between plutons east and west of the Saint John River are required in order to determine whether or not they are related.

In conclusion, it is clear that plutonic rocks in southern New Brunswick vary in compositional and deformational history and are unlikely to be all similar in age. Hence individual names should be used for these plutons, and the use of "Golden Grove Suite" as an umbrella term for these disparate intrusions should be discontinued. However, more U-Pb dating is required in order to test the interpretation that plutons in the Saint John area are Cambrian in age.

\section{ACKNOWLEDGEMENTS}

The study of plutonic rocks in the Saint John area was funded by a Natural Sciences and Engineering Research Council Operating Grant, an Acadia University Research Grant to SMB and a contract with the Geological Survey of Canada as part of the Canada-New Brunswick Cooperation Agreement on Mineral Development. We thank K.L. Currie and R.D. Nance for stimulating field trips and discussions that contributed to our understanding of the geology of the Saint John area. MLB thanks the technical staff of the Geochronology Laboratory of the Geological Survey of Canada for their help in generating the U-Pb data, and $\mathrm{J}$. Mortensen for helpful discussions of the $\mathrm{U}-\mathrm{Pb}$ data.

ALCOCK, F.J. 1938. Geology of the Saint John region. Geological Survey of Canada, Memoir 216, 65 p.

BAILEY, L.W. 1865. Observations on geology of southem New Brunswick. Canadian Naturalist, 2, pp. 232-239, 314-318.

BAILEY, L.W., MATTHEW, G.F., and ELLS, R.W. 1880. Report on the geology of southern New Brunswick, embracing the counties of Charlotte, Sunbury, Queens, Kings, St. John, and Albert. Geological Survey of Canada, Report of Progress for 1878-79, pp. 1-26D.

BARR, S.M. and WHITE, C.E. 1988. Petrochemistry of contrasting late Precambrian volcanic and plutonic associations, Caledonian Highlands, southem New Brunswick. Maritime Sediments and Atlantic Geology, 24, pp. 353-372.

1989. Re-interpretation of Precambrian stratigraphy in southern New Brunswick. In Fourteenth Annual Review of Activities. Edited by S.A. Abbott. New Brunswick Department of Natural Resources and Energy, Minerals and Energy Division, Information Circular 89-2, pp. 182-189.

BARR, S.M., WHITE, C.E., and BEVIER, M.L. 1990. Contrasting petrochemistry and age of plutonic rocks in the Saint John area and 
Caledonian Highlands, Kings and Saint John counties, southem New Brunswick. In Fourteenth Annual Review of Activities. Edited by S.A. Abbott. New Brunswick Department of Natural Resources and Energy, Minerals and Energy Division, Information Circular 90-2, pp. 178-186.

BEVIER, M.L. and BARR, S.M. 1990. U-Pb age constraints on the stratigraphy and tectonic history of the Avalon terrane, New Brunswick, Canada. Joumal of Geology, 98, pp. 53-63.

BEVIER, M.L., WHITE, C.E., and BARR, S.M. 1990. Late Precambrian U-Pb ages for the Brookville Gneiss, southem New Brunswick. Journal of Geology, 98, pp. 955-965.

COWIE, J.W. and JOHNSON, M.R.W. 1985. Late Precambrian and Cambrian geological time-scale. In The chronology of the geological record. Edited by N.J. Snelling. Geological Society of London, Memoir 10, pp. 47-64.

CUMMING, C.L. 1916. The igneous rocks of Saint John, New Brunswick. Unpublished Ph.D. thesis, Princeton University, Princeton, New Jersey, 344 p.

CURRIE, K.L. 1986. The stratigraphy and structure of the Avalonian Terrane around Saint John, New Brunswick. Maritime Sediments and Atlantic Geology, 22, pp. 278-295.

CURRIE, K.L. 1987. Late Precambrian igneous activity and its tectonic implications, Musquash-Loch Alva region, southern New Brunswick. In Current Research, Part A, Geological Survey of Canada, Paper 87-1A, pp. 663-671.

1988a. The westem end of the Avalon zone in southem New Brunswick. Maritime Sediments and Atlantic Geology, 24, pp. 339-352.

1988b. Saint George map area: the end of the Avalon zone in southem New Brunswick. In Current Research, Part B, Geological Survey of Canada, Paper 88-1B, pp. 9-16.

CURRIE, K.L., NANCE, R.D., PAJARI, G.E., and PICKERILL, R.K. 1981. Some aspects of the pre-Carboniferous geology of Saint John, New Brunswick. In Current Research, Part A, Geological Survey of Canada, Paper 81-1A, pp. 23-30.

DALLMEYER, R.D. and NANCE, R.D. $1989 .{ }^{40} \mathrm{Ar} / 9 \mathrm{Ar}$ mineral age record of polyphase tectonothermal activity in the Avalon Terrane of southem New Brunswick. In Geological Association of Canada/ Mineralogical Association of Canada, Program with Abstracts, 14, p. A126.

DEVEAU, K.A. 1989. Petrology of the Golden Grove Intrusive Suite in the area northeast of Saint John, New Brunswick. Unpublished B.Sc thesis, Acadia University, 145 p.

DICKSON, W.L. 1983. Geology, geochemistry and petrology of the Precambrian and Carboniferous igneous rocks between Saint John and Beaver Harbour, southem New Brunswick. Unpublished Ph.D. thesis, University of New Brunswick, 409 p.

HAYES, A.O. and HOWELL, G.G. 1937. Geology of Saint John, New Brunswick. Geological Society of America, Special Paper 5, $146 \mathrm{p}$.

HOFMANN, H.J. 1974. The stromatolite Archaeozoon acadiense from the Proterozoic Green Head Group of Saint John, New Brunswick. Canadian Journal of Earth Sciences, 11, pp. 1098-1115.

INTERNATIONAL SUBCOMMISSION ON STRATIGRAPHIC CLASSIFICATION. 1987. Stratigraphic classification and nomenclature of igneous and metamorphic rock bodies. Geology, 99. pp. 440-442.

MATTHEW, W.D. 1894. The intrusive rocks near St. John, New Brunswick. Transactions of the New York Academy of Sciences, 13, pp. 185-302.

NANCE, R.D. 1986. Precambrian evolution of the Avalon terrane in the northern Appalachians: A review. Maritime Sediments and Atlantic Geology, 22, pp. 214-238.
1987. Model for the Precambrian evolution of the Avalon terrane in southem New Brunswick, Canada. Geology, 15, pp. 753 756.

O'BRIEN, S.J., WARDLE, R.J., and KING, A.F. 1983. The Avalon Zone: a Pan-African terrane in the Appalachian Orogen of Canada. Geological Joumal, 18, pp. 195-222.

ODIN, G.S., GALE, N.H., and DORE, F. 1985. Radiometric dating of the late Precambrian times. In The chronology of the geological record. Edited by N.J. Snelling. Geological Society of London. Memoir 10, pp. 65-72.

OLSZEWSKI, W.J., Jr. and GAUDETTE, H.E. 1982. Age of the Brookville gneiss and associated rocks, southeastern New Brunswick. Canadian Journal of Earth Sciences, 19, pp. 2158-2166.

OLSZEWSKI, W.J., Jr., GAUDETTE, H.E., and POOLE, W.H. 1980. $\mathrm{Rb}-\mathrm{Sr}$ whole rock and U-Pbzircon ages from the Greenhead Group, New Brunswick. Geological Society of America, Abstracts with Program, 12, p. 76.

PAKTUNC, A.D. 1989. Platinum-group-element mineralization in the Mechanic Settlement Intrusion, Kings County, New Brunswick. In Fourteenth Annual Review of Activities. Edited by S.A. Abbott. New Brunswick Department of Natural Resources and Energy, Minerals and Energy Division, Information Circular 89-2, pp. 213 214.

PALMER, A.R. 1983. The Decade of North American Geology 1983 Geologic time scale. Geology, 9, pp. 503-504.

PITCHER, W.S. 1987. Granites and yet more granites forty years on. Geologische Rundschau, 76, pp. 51-79.

RAST, N., O'BRIEN, B.H., and WARDLE, R.J. 1976. Relationships between Precambrian and lower Paleozoic rocks of the "Avalon Platform" in New Brunswick, the northeast Appalachians, and the British Isles. Tectonophysics, 30, pp. 315-338.

RODDICK, J.C. 1987. Generalized numerical error analysis with applications to geochronology and thermodynamics. Geochimica et Cosmochimica Acta, 51, pp. 2129-2135.

RUITENBERG, A.A., GILES, P.S., VENUGOPAL, D., BUTTIMER, S.M., McCUTCHEON, S.R., and CHANDRA, J. 1979. Geology and mineral deposits, Caledonia area. New Brunswick Department of Natural Resources, Memoir 1, 165 p.

STACEY, J.S. and KRAMERS, J.D. 1975. Approximation of terrestrial lead isotope evolution by a two-stage model. Earth and Planetary Science Letters, 26, pp. 207-221.

STEIGER, R.H. and JÄGER, H. 1977. Subcommision on geochronology: convention on the use of decay constants in geo- and cosmochronology. Earth Planetary Science Letters, 36, pp. 359-362.

STRECKEISEN, A. 1976. To each plutonic rock its proper name. Earth Science Reviews, 12, pp. 1-23.

WARDLE, R.J. 1978. The stratigraphy and tectonics of the Green Head Group: Its relation to Hadrynian and Paleozoic rocks, southem New Brunswick. Unpublished Ph.D. thesis, University of New Brunswick, Fredericton, New Brunswick, 295 p.

WATTERS, S.E. 1987. Gold-bearing rocks - Bay of Fundy coastal zone. In Twelfth Annual Review of Activities. Edited by S.A. Abbott. New Brunswick Department of Natural Resources and Energy, Minerals and Energy Division, Information Circular 87-2, pp. 4144.

WHITE, C.E., BARR, S.M., and BEVIER, M.L. 1990a. Late Precambrian U-Pb ages for the Brookville Gneiss, southem New Brunswick: implications for stratigraphy of the Avalon Terrane. Abstract in Atlantic Geology, 26, p. 189.

WHTTE, C.E., BEVIER, M.L., and BARR, S.M. 1990b. New U-Pb ages for the Brookville Gneiss and revised Avalonian stratigraphy in the Canadian Appalachian orogen. Geological Society of America, 